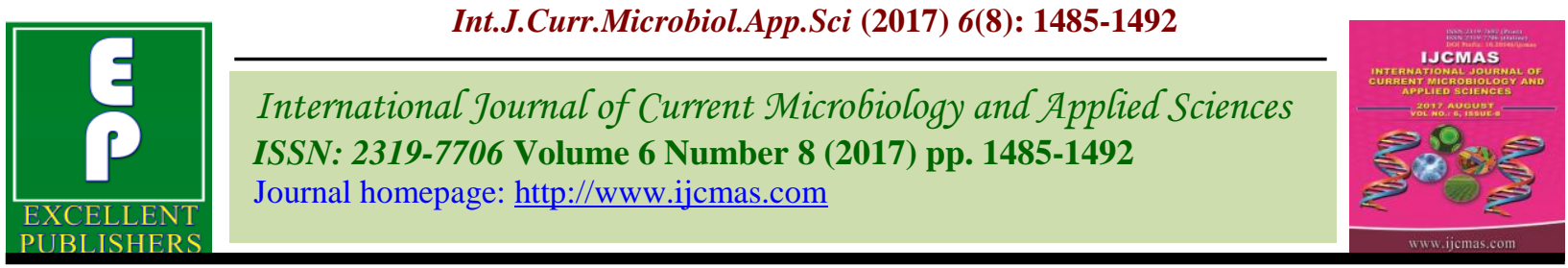

Original Research Article

https://doi.org/10.20546/ijcmas.2017.608.179

\title{
Quality Evaluation and Preparation of Jam from Sweet Potato Cultivars
}

\author{
Chhama Devi*, Laureate Hynniewta and Surajit Mitra
}

Department of Post-Harvest Technology of Horticultural Crops, Bidhan Chandra Krishi

Viswavidyalaya, Mondouri, Nadia District, West Bengal, India

*Corresponding author

\section{A B S T R A C T}

A comparative study was done to determine the most suitable combination

Keywords

Sweet potato,

Jam.

Article Info

Accepted:

17 June 2017

Available Online:

10 August 2017 of two cultivars of sweet potato for jam preparation incorporated within the ratios $\mathrm{T}_{1}=\mathrm{TSP} 12-14(100 \%), \mathrm{T}_{2}=\mathrm{TSP} 12-8(100 \%), \mathrm{T}_{3}=\mathrm{TSP} 12-8+$ TSP $12-14\left(50 \%\right.$ each), $\mathrm{T}_{4}=$ TSP $12-14(75 \%)+$ TSP $12-8(25 \%), \mathrm{T}_{5}=$ TSP $12-14(25 \%)+$ TSP $12-8(75 \%)$. All the jam samples prepared from sweet potato were stored in sterilized glass jars and evaluated physicochemically for ascorbic acid, $\mathrm{pH}$, total soluble solids, reducing sugars and non-reducing sugars, total sugar and sensory evaluation for an interval of 0 day, 30 days, and 60 days. For jam preparation treatment TSP-12-14 (100\%) shows better biochemical retentions up to 60 days of storage along with good overall acceptability.

\section{Introduction}

Sweet potato (Ipomoea batatas) is a dicotyledonous plant which belongs to the family of Convolvulacea. Sweet potato is cultivated extensively for its nutritious and health-promoting values (FAO, 2012; Lee et $a l ., 2012$ ) and also plays an important role in food security. The production reached over 100 million tons in 2014 (FAOSTAT, 2016). Sweet potato is ranked one of the most important food crop after rice, wheat, potato, maize, and cassava (Shekhar et al., 2015). The total production in India is about 1338 thousand tons and area is 110.63 thousands hectare. In West Bengal the area under sweet potato cultivation is 22.85 thousands hectare and production of sweet potato is about 442.28 thousand tons. Sweet potato often considered as an "almost perfectly nourishing food", contains vitamins, iron, calcium, zinc, proteins, minerals, and many other nutrients at favorable ratios (Woolfe, 1992). The starch, crude fiber, protein, ash, and fat of tubes from 80 sweet potatoes varieties had ranges of 42.4-77.3, 1.9-6.4, 1.3-9.5, 1.1-4.9, and 0.23.0/100 g of dry matter, respectively (Oboh et al., 1989; Ravindran et al., 1995; Ishida et al., 2000; Mei et al., 2010; Dincer et al., 2011). The development of processed products from sweet potato presents one of the most important key to the expended utilization of the crop. There are a number of products that can be made by using sweet potato as a major ingredient and the development of new and improved processed products from sweet 
potato appears to represent an excellent means of increasing the utilization of this high yielding and nutritious crop (Singh et al., 2003). Sweet potato contains water-soluble pectin, which enables its use in making jams and jellies. The process consists of cooking a mixture of $20.7 \%$ sweet potato, $45 \%$ sugar, $34 \%$ water, and $0.3 \%$ citric acid until solids content of 68-Brix was reached (Truong et al., 1986). Due to high starch content of sweet potato, compared to fruits, the jam has a slightly different consistency (Truong, 1987). Lila and Babu Nambisan (1991) have reported the abundance of nutrients in sweet potato. Sensory evaluation of fruit flavored sweet potato jam scored high for taste, but gelling consistency was slightly softer than fruit jam due to the high content of starch in the roots.

\section{Materials and Methods}

The experiment was carried out in the department of Post-Harvest Technology of Horticultural Crops, Faculty of Horticulture, Bidhan Chandra Krishi Viswavidyalaya, Mohanpur, Nadia West Bengal, during the period from 2015-2017. Tubers of sweet potato were obtained from Horticulture Research Station, Bidhan Chandra Krishi Viswavidyalaya, Mondouri, Nadia District, West Bengal.

\section{Preliminary preparation for experiment}

The sweet potato tubers were harvested after 120 days of planting, when the tubers latex did not become black after cutting. The following preliminary preparations were done.

\section{Washing}

Sweet potato were washed in tap water after that in distilled water containing $50 \mathrm{ppm}$ of chlorine to get rid of any foreign material that may be adhering to the tuber surface and also to reduce the microbial count.

\section{Drying}

There after the sweet potato tubers were dried with the help of electric fan.

\section{Methodology of Jam Processing}

\section{Evaluation of physico-chemical properties}

\section{Moisture content (\%)}

The sample was dried in drier at $65^{\circ} \mathrm{C}$ and initial and final weight was recorded by weighing balance.

Final value - initial value

$(\%)$ moisture $=$----------------------- $\times 100$
Initial value

\section{Dry matter content (\%)}

Dry matter of harvested tubers of different cultivars was recorded in gram after drying the samples in drier at $65^{\circ} \mathrm{C}$ for few hours.

\section{Total soluble solid $\left({ }^{0} \mathbf{B}\right)$}

A total soluble solid was determined by using a Hand Refract meter from the extract of sweet potato tuber harvested at 120 days after planting.

\section{Ascorbic acid (mg/100g)}

Estimated using 2, 6 dichloro-endophenol dye titration method. (Ranganna, 2000). Ascorbic acid reduces the 2, 6-dichlorophenol indophenols dye to a colorless leuco-base.the ascorbic acid gets oxidized to dehydro ascorbic acid.

Though the dye is blue colored compound, the end product is the appearance of pink 
color. The dye is pink color in acidic medium. Metaphosphoric acid is used as the titrating agent.

\section{Reducing sugar $(\%)$}

Sugar level was determined by copper reduction method (Ranganna, 2000).

\section{Total sugar $(\%)$}

Sugar level was determined by copper reduction method (Ranganna, 2000).

\section{Non reducing sugar $(\%)$}

Non reducing sugar content was determined by deducting the reducing sugar from the total sugar content.

\section{Sensory evaluation}

It was done using the 9 points hedonic score as given by Ranganna (2000).

\section{Results and Discussion}

\section{Total soluble solids $\left({ }^{0} \mathrm{~B}\right)$}

Total soluble solids of jams were successfully controlled according to the desired ranges. In the initial stage the TSS was maintained $68 \%$. There was little amount of variation in the TSS as it was found highest in the treatment $\mathrm{T}_{4}\left(68.86^{\circ} \mathrm{Brix}\right)$ and lowest in $\mathrm{T}_{5}$ $\left(68.268^{\circ} \mathrm{Brix}\right)$. After 60 days of storage it was found that the highest amount of TSS was in the treatment $\mathrm{T}_{2}\left(70.4^{0} \mathrm{Brix}\right)$ followed by $\mathrm{T}_{1}$ $\left(70.35^{\circ} \mathrm{Brix}\right)$. The lowest value was noticed in $\mathrm{T}_{4}\left(69.6^{0} \mathrm{Brix}\right)$.

Storage effect on TSS was significant which increased from mean value of $68.57 \%$ to $70.16 \%$. Respectively after 60 days of storage. Several researchers have observed an increase in total soluble solids of fruit products during storage. This is obviously due to the loss of moisture. The increase in TSS of jam during storage might be due to conversion of polysaccharides into soluble sugars. Similar inferences were drawn by the findings of Manivasagan et al., (2004) in karonda jam.

\section{pH}

Results regarding $\mathrm{pH}$ of jams after 60 days of storage showed that a range of $\mathrm{pH}-3.43$ to $\mathrm{pH}-$ 3.5 was recorded with mean of 3.614 initial and 3.467 after 60 days of storage. It was also observed that as the storage period was prolonged, the $\mathrm{pH}$ values decreased with a small variation. This may be due to increase in acidity. Panday and Singh (1999) also reported that the higher acidity may account due to lower $\mathrm{pH}$ value.

\section{Total sugar content (\%)}

After 60 days of storage there was significant difference in the total sugar content of jam with maximum value observed in $\mathrm{T}_{1}$ $(32.833 \%)$ and minimum in $\mathrm{T}_{3}(32.18 \%)$. A decrease in the total sugar content was observed with mean value varies from $32.94 \%$ to $32.50 \%$.

\section{Reducing sugars}

Reducing sugars showed increasing trend. Minimum value of $23.88 \%$ in $\mathrm{T}_{4}$ and maximum $24.345 \% \mathrm{~T}_{2}$ were observed during 60 days of storage respectively. Initial mean value $19.125 \%$ of reducing sugars and $24.05 \%$ were obtained after 60 days of storage. The increase in reducing sugars is in agreement with Riaz et al., (1999).

Non - reducing sugar $(\%)$

Non reducing sugar decreased in 60 days after storage. A maximum value of $8.640 \%$ in $\mathrm{T}_{1}$ and minimum of $8.165 \%$ in $\mathrm{T}_{2}$ was observed at 60 days of storage. Mean value of $13.81 \%$ 
in initial storage days and $8.455 \%$ were obtained after 60 days of storage. Riaz et al.,
(1999) also observed the same results regarding non-reducing sugars.

Table.1 Effect on TSS, pH, total sugar, reducing sugar, non-reducing sugar, ascorbic acid and Sensory quality of jam during storage

\begin{tabular}{|c|c|c|c|}
\hline \multirow[b]{2}{*}{ Treatments } & \multicolumn{3}{|c|}{ Storage Interval (days) Total soluble solids $\left({ }^{0} \mathrm{~B}\right)$} \\
\hline & $\mathbf{0}$ & 30 & 60 \\
\hline $\mathbf{T}_{1}$ & 68.388 & 69.378 & 70.350 \\
\hline $\mathbf{T}_{2}$ & 68.818 & 69.198 & 70.498 \\
\hline $\mathbf{T}_{3}$ & 68.515 & 68.853 & 70.160 \\
\hline $\mathbf{T}_{4}$ & 68.868 & 69.103 & 69.600 \\
\hline$T_{5}$ & 68.268 & 69.858 & 70.228 \\
\hline MEAN & 68.57 & 69.27 & 70.16 \\
\hline $\operatorname{S.Em}( \pm)$ & 0.109 & 0.132 & 0.032 \\
\hline C.D.(0.05) & 0.33 & 0.39 & 0.097 \\
\hline
\end{tabular}

\begin{tabular}{|c|c|c|c|}
\hline \multirow{2}{*}{ Treatments } & \multicolumn{3}{|c|}{ Storage Interval (days) $\mathbf{p H}$} \\
\cline { 2 - 4 } & $\mathbf{0}$ & $\mathbf{3 0}$ & $\mathbf{6 0}$ \\
\hline $\mathbf{T}_{\mathbf{1}}$ & 3.638 & 3.563 & 3.500 \\
\hline $\mathbf{T}_{\mathbf{2}}$ & 3.635 & 3.555 & 3.495 \\
\hline $\mathbf{T}_{\mathbf{3}}$ & 3.618 & 3.538 & 3.478 \\
\hline $\mathbf{T}_{\mathbf{4}}$ & 3.583 & 3.488 & 3.430 \\
\hline $\mathbf{T}_{\mathbf{5}}$ & 3.595 & 3.485 & 3.430 \\
\hline MEAN & 3.614 & 3.53 & 3.467 \\
\hline S.Em( \pm () & 0.0064 & 0.0041 & 0.0031 \\
\hline C.D.(0.05) & 0.019 & 0.0125 & 0.0093 \\
\hline
\end{tabular}

\begin{tabular}{|c|c|c|c|}
\hline \multirow{2}{*}{ Treatments } & \multicolumn{3}{|c|}{ Storage Interval (days) Total sugar percentage } \\
\cline { 2 - 4 } & $\mathbf{0}$ & $\mathbf{3 0}$ & $\mathbf{6 0}$ \\
\hline $\mathbf{T}_{\mathbf{1}}$ & 33.335 & 32.873 & 32.833 \\
\hline $\mathbf{T}_{\mathbf{2}}$ & 33.165 & 32.545 & 32.508 \\
\hline $\mathbf{T}_{\mathbf{3}}$ & 32.915 & 32.283 & 32.180 \\
\hline $\mathbf{T}_{\mathbf{4}}$ & 32.553 & 32.530 & 32.470 \\
\hline $\mathbf{T}_{\mathbf{5}}$ & 32.723 & 32.695 & 32.540 \\
\hline MEAN & 32.94 & 32.58 & 32.50 \\
\hline S.Em( \pm (.) & 0.23 & 0.053 & 0.049 \\
\hline C.D.(0.05) & $\mathrm{NS}$ & 0.16 & 0.149 \\
\hline & & & \\
\hline
\end{tabular}

\begin{tabular}{|c|c|c|c|}
\hline \multirow{2}{*}{ Treatments } & \multicolumn{3}{|c|}{ Storage Interval (days) Reducing sugar content (\%) } \\
\cline { 2 - 4 } & $\mathbf{0}$ & $\mathbf{3 0}$ & $\mathbf{6 0}$ \\
\hline $\mathbf{T}_{\mathbf{1}}$ & 19.313 & 21.530 & 24.188 \\
\hline $\mathbf{T}_{\mathbf{2}}$ & 19.350 & 21.710 & 24.345 \\
\hline $\mathbf{T}_{\mathbf{3}}$ & 19.228 & 21.050 & 23.933 \\
\hline $\mathbf{T}_{\mathbf{4}}$ & 18.798 & 20.225 & 23.888 \\
\hline $\mathbf{T}_{\mathbf{5}}$ & 18.935 & 20.748 & 2.903 \\
\hline MEAN & 19.125 & 21.053 & 24.05 \\
\hline S.Em( \pm () & 0.036 & 0.059 & 0.042 \\
\hline C.D.(0.05) & 0.11 & 0.179 & 0.127 \\
\hline
\end{tabular}

\begin{tabular}{|c|c|c|c|}
\hline \multirow{2}{*}{ Treatments } & \multicolumn{3}{|c|}{ Storage Interval (days) Non reducing sugar content (\%) } \\
\cline { 2 - 4 } & $\mathbf{0}$ & $\mathbf{3 0}$ & $\mathbf{6 0}$ \\
\hline $\mathbf{T}_{\mathbf{1}}$ & 14.023 & 11.343 & 8.640 \\
\hline $\mathbf{T}_{\mathbf{2}}$ & 13.815 & 10.835 & 8.165 \\
\hline $\mathbf{T}_{\mathbf{3}}$ & 13.688 & 11.233 & 8.248 \\
\hline $\mathbf{T}_{\mathbf{4}}$ & 13.773 & 12.305 & 8.583 \\
\hline $\mathbf{T}_{\mathbf{5}}$ & 13.788 & 11.948 & 8.638 \\
\hline
\end{tabular}




\begin{tabular}{|c|c|c|c|}
\hline MEAN & 13.81 & 11.533 & 8.455 \\
\hline S.Em( \pm ) & 0.237 & 0.052 & 0.071 \\
\hline C.D.(0.05) & NS & 0.157 & 0.214 \\
\hline \multirow{2}{*}{ Treatments } & \multicolumn{2}{|c|}{ Storage Interval (days) Ascorbic Acid Content (mg/100gm) } \\
\cline { 2 - 4 } & $\mathbf{0}$ & $\mathbf{3 0}$ & $\mathbf{6 0}$ \\
\hline $\mathbf{T}_{\mathbf{1}}$ & 26.458 & 25.848 & 25.733 \\
\hline $\mathbf{T}_{\mathbf{2}}$ & 19.315 & 19.085 & 18.855 \\
\hline $\mathbf{T}_{\mathbf{3}}$ & 15.220 & 15.040 & 14.720 \\
\hline $\mathbf{T}_{\mathbf{4}}$ & 17.950 & 17.620 & 17.285 \\
\hline $\mathbf{T}_{\mathbf{5}}$ & 14.580 & 14.273 & 14.108 \\
\hline MEAN & 18.705 & 18.37 & 0.176 \\
\hline S.Em( $\mathbf{(})$ & 0.107 & 0.141 & 0.249 \\
\hline C.D.(0.05) & 0.322 & 0.426 & \\
\hline
\end{tabular}

\begin{tabular}{|c|c|c|c|}
\hline \multirow{2}{*}{ Treatments } & \multicolumn{3}{|c|}{ Storage Interval (days) Colour } \\
\cline { 2 - 4 } & $\mathbf{0}$ & $\mathbf{3 0}$ & $\mathbf{6 0}$ \\
\hline $\mathbf{T}_{\mathbf{1}}$ & 8.250 & 8.000 & 7.500 \\
\hline $\mathbf{T}_{\mathbf{2}}$ & 8.000 & 7.750 & 7.250 \\
\hline $\mathbf{T}_{\mathbf{3}}$ & 7.750 & 7.250 & 7.000 \\
\hline $\mathbf{T}_{\mathbf{4}}$ & 8.000 & 7.750 & 7.500 \\
\hline $\mathbf{T}_{\mathbf{5}}$ & 7.750 & 7.500 & 7.000 \\
\hline S.Em( $\mathbf{(})$ & 0.266 & 0.237 & 0.214 \\
\hline C.D.(0.05) & $\mathrm{NS}$ & $\mathrm{NS}$ & $\mathrm{NS}$ \\
\hline
\end{tabular}

\begin{tabular}{|c|c|c|c|}
\hline \multirow{2}{*}{ Treatments } & \multicolumn{3}{|c|}{ Storage Interval (days) Taste } \\
\cline { 2 - 4 } & $\mathbf{0}$ & $\mathbf{3 0}$ & $\mathbf{6 0}$ \\
\hline $\mathbf{T}_{\mathbf{1}}$ & 9.000 & 8.750 & 8.250 \\
\hline $\mathbf{T}_{\mathbf{2}}$ & 8.750 & 8.500 & 7.750 \\
\hline $\mathbf{T}_{\mathbf{3}}$ & 8.500 & 8.250 & 8.000 \\
\hline $\mathbf{T}_{\mathbf{4}}$ & 8.250 & 8.250 & 7.500 \\
\hline $\mathbf{T}_{\mathbf{5}}$ & 8.500 & 8.250 & 8.000 \\
\hline S.Em( $\mathbf{n})$ & 0.24 & 0.258 & 0.204 \\
\hline C.D.(0.05) & $\mathrm{NS}$ & $\mathrm{NS}$ & $\mathrm{NS}$ \\
\hline
\end{tabular}

\begin{tabular}{|c|c|c|c|}
\hline \multirow{2}{*}{ Treatments } & \multicolumn{3}{|c|}{ Storage Interval (days) Overall Acceptability } \\
\cline { 2 - 4 } & $\mathbf{0}$ & $\mathbf{3 0}$ & $\mathbf{6 0}$ \\
\hline $\mathbf{T}_{\mathbf{1}}$ & 9.000 & 8.750 & 8.000 \\
\hline $\mathbf{T}_{\mathbf{2}}$ & 9.000 & 8.750 & 8.000 \\
\hline $\mathbf{T}_{\mathbf{3}}$ & 8.750 & 8.500 & 7.750 \\
\hline $\mathbf{T}_{\mathbf{4}}$ & 8.500 & 8.250 & 7.500 \\
\hline $\mathbf{T}_{\mathbf{5}}$ & 8.500 & 8.000 & 7.750 \\
\hline S.Em( $\mathbf{(})$ & 0.214 & 0.232 & 0.204 \\
\hline C.D.(0.05) & $\mathrm{NS}$ & $\mathrm{NS}$ & $\mathrm{NS}$ \\
\hline
\end{tabular}

Recipe (Padmaja and Premkumar, 2002)

\begin{tabular}{|c|c|}
\hline Ingredients & Quantity \\
\hline Sweet potato pulp & $1 \mathrm{~kg}$ \\
Sugar & $900 \mathrm{~g}$ \\
Citric acid & $10 \mathrm{~g}$ \\
Pectin & $5 \mathrm{~g}$ \\
\hline
\end{tabular}




\section{(Flow Chart for Preparation of Sweet Potato Jam)}

Sweet potato tuber

Washing and peeling

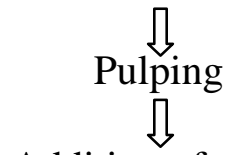

Addition of sugar

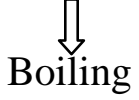

(With continuous stirring)

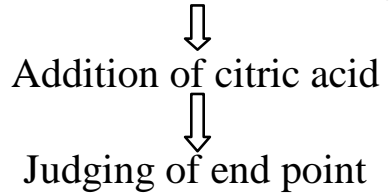

(Up to $105^{\circ} \mathrm{C}$ or $68-70$ TSS or by sheet test or by Drop test)

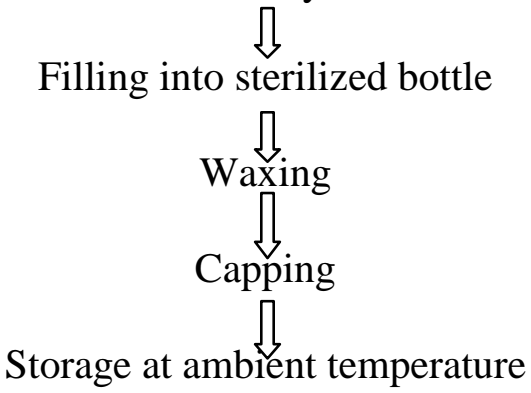

\section{Ascorbic acid content (mg/100g)}

A gradual decrease was observed after 60 days of storage. Storage mean valued decreased from $18.705 \mathrm{mg} / 100 \mathrm{~g}$ to 18.14 $\mathrm{mg} / 100 \mathrm{~g}$. Highest value was observed in $\mathrm{T}_{1}$ and lowest in $\mathrm{T}_{5}$ after 60 days of storage.

The slight reduction in ascorbic acid might be due to oxidation of residual oxygen in glass bottles. Similar results were reported by Karla and Revanthi (1983); Vidhya and Narain (2011) (Table 1).

\section{Sensory profile of sweet potato jam}

\section{Colour}

The result of present investigation clearly indicated that the colour rating of jam decreased with increases in storage period. It was observed that the colour and appearance slightly decreased from initial day of storage up to 60 days. This might be due to loss of ascorbic acid content due to oxidation reaction during storage. These results corroborated the findings of Hamanan et al., (1980), Baramanray et al., (1995).

\section{Taste}

The result for taste indicated that the higher rating 9 was obtained from the treatment $\mathrm{T}_{1}$ while, minimum rating 8.25 was seen in treatment $T_{4}$ during initial days of storage and it was decreased after 60 days of storage with maximum in $T_{1}$ (8.25) and minimum in $T_{4}$ (7.5). The rating of taste decrease might be due to higher T.S.S value. These findings were in conformity with the results reported by Hamanan et al., (1980); Baramanray et al., (1995). 


\section{Overall acceptability}

The overall acceptability of jam was dependent on colour or appearance and taste rating of the product. As the period of storage prolonged, the overall acceptability showed a decreasing trend. The possible reason might be due to decrease in rating of colour flavour, taste and texture of jam. These results were supported by the finding of Hamanan et al., (1980), Baramarnaray et al., (1995).

Experiment was conducted by imposing five treatments and four replications. The main objective is to determine the various physical chemical properties of the cultivars. Some results are stated below:

Shelf life of sweet potato was extended by converting into processed products after 60 days of storage.

In jam preparation treatment $T_{1}$ shows better biochemical retentions up to 60 days of storage along with good overall acceptability.

\section{References}

Dincer, C., Karaoglan, M., Erden, F., Tetik, N., Topuz, A. and Ozdemir, F. (2011). Effects of baking and boiling on the nutritional and antioxidant properties of sweet potato [Ipomoea batatas (L.) Lam.] Cultivars. Plant Foods for Human Nutr, 66: 341-347.

FAO (Food and Agriculture Organization of the United Nations) (2012). http://www. feedipedia.org/node/745.

FAOSTAT (Statistics division of Food and Agriculture Organization of the United Nations) (2016). http://faostat3.fao.org/browse/Q/*/E.

Hamanan, S. W., Bains, G. S. and Singh, K. K. (1980). Studies on the processing of pink and white fleshed guava varities for pulp. Punj. Hort. J., 20 (1-2): 179-
189.

Ishida, H., Suzuno, H., Sugiyama, N., Innami, S., Tadokoro, T. and Maekawa, A. (2000). Nutritive evaluation on chemical components of leaves stalks and stems of sweet potatoes (Ipomoea batatas poir). Food Chem., 68: 359367.

Karla, S. K. and Revanthi, G. (1983). Chemical and microbial evolution of storage guava pulp in P. C. V. container. J. Food Sci. High Tech. Vinogradarstvo, (1): 11-13.

Lee, M. J., Park, J. S., Choi, D. S. and Jung, M. Y. (2012). Characterization and quantitation of anthocyanins in purplefleshed sweet potatoes cultivated in Korea by HPLCDAD and HPLC-ESIQTOF-MS/MS. J. of Agri. and Food Chem., 61: 3148-3158.

Lila Babu and Nambisan, B. (1991). Role of beta amylase in starch breakdown during processing of sweet potato (under publication).

Manivasagan, S., Rana, G. S., Surinder, K. and Joon, M. S. (2004). Qualitative changes in jam of karonda during storage at room temperature. Haryana J. of Horti. Sci., 33 (3-4): 216-217

Mei, X., Mu, T. H. and Han, J. J. (2010). Composition and physicochemical properties of dietary fiber extracted from residues of 10 varieties of sweet potato by a sieving method. J. of Agri. and Food Chem., 58: 7305-7310.

Oboh, S., Ologhobo, A., and Tewe, O. (1989). Some aspects of the biochemistry and nutritional value of the sweetpotato (Ipomoea batatas). Food Chem., 31: 918.

Padmaja, G. and Premkumar, T., (2002). Tuber crop recipes, technical bulletin series 36, CTCRI, Kerala India 26.

Pandey, A. K. and Singh, J. S. (1999). Studies on preparation and preservation of guava ready-to-serve beverage. Indian 
J. Hort., 56 (2): 130-132.

Ranganna, S. (2000). In: Handbook of Analysis and Quality Control for fruits and vegetable Products. $2^{\text {nd }}$ Edition, Tata McGraw Hill Publication Company Ltd. New Delhi.

Ravindran, V., Ravindran, G., Sivakanesan, R. and Rajaguru, S. B. (1995). Biochemical assessment of tubers from 16 cultivars of sweet potato (Ipomoea batatas L.). J. of Agri. and Food Chem., 43: 2646-2651.

Riaz, M. N., Mohyuddin, G. and Al-Haq, M. I. (1999). Physical, chemical and sensory characteristics of jams made from fresh and frozen strawberries. Pakistan J. Arid Agric., 2 (1): 51-60.

Shekhar, S., Mishra, D., Buragohain, A. K., Chakraborty, S. and Chakraborty, N. (2015). Comparative analysis of phytochemicals and nutrient availability in two contrasting cultivars of sweet potato (Ipomoea batatas L.). Food Chem., 173: 957-965.

Singh, T.V., Shivhare, U.S. and Beniwal, V.S.
(2003). Rheological, textural and spectral characteristics of sorbitol substituted mango jam. J. of Food Eng., 105: 503-512.

Truong, V. D. (1987). New development in processing sweet potato for food. International sweet potato symposium, 20-26, Visca, Philippines.

Truong, V. D., Biermann, C. J. and Marlett, J. A. (1986). Simple sugars, oligosaccharides, and starch concentrations in raw and cooked sweet potato. J. Agric. Food Chem., 34: 421425.

Vidhya, R. and A. Narain A. (2011). Formulation and evaluation of preserved products utilizing under exploited fruit, wood apple (Limonia acidissima). American-Eurasian J. Agric. and Environ. Sci., 10 (1): 112118.

Woolfe, J. A. (1992). Sweet Potato: An Untapped Food Resource. Cambridge University Press. Cambridge, U. K. 643.

\section{How to cite this article:}

Chhama Devi, Laureate Hynniewta and Surajit Mitra. 2017. Quality Evaluation and Preparation of Jam from Sweet Potato Cultivars. Int.J.Curr.Microbiol.App.Sci. 6(8): 1485-1492. doi: https://doi.org/10.20546/ijcmas.2017.608.179 